\title{
Polish mathematics education periodicals in times of educational reform after the collapse of the Warsaw Pact
}

\author{
Ewa Swoboda ${ }^{1} \cdot$ Marcin Karpiński ${ }^{2} \cdot$ Małgorzata Zambrowska $^{3}$
}

Accepted: 28 April 2021 / Published online: 12 May 2021

(c) The Author(s) 2021

\begin{abstract}
In this paper we present a study of the most important Polish periodicals of the last 30 years that are related to mathematics education. Our research aim was to analyse how the changes in mathematics education that were caused by a new political situation in Poland were reflected in education journals. Journals that shaped Polish mathematics education varied significantly. We analysed both those journals that have a long history and those that arose spontaneously, thus reflecting the mood of this time of great change. Our analysis leads to the conclusion that journals, where the authors are mostly mathematics scientists or university lecturers, turned out to be in different to shifts in the educational system. A characteristic tendency reflecting the mood of times of change was the creation of new magazines, which were to be forums for sharing views on teaching mathematics. It turns out, however, that the journals created after 1990 had quite a short lifespan. Education journals that were directed to teachers for decades constituted a platform for discussion of new ideas and teaching styles, too. They offered a place to exchange opposing views. However, this situation slowly ceased to apply.
\end{abstract}

Keywords Changes in schools' structure $\cdot$ Curricula $\cdot$ Examination systems $\cdot$ Mathematics education periodicals $\cdot$ Platform for discussion $\cdot$ Reforms of the education system

\section{Introduction}

This study is dedicated to the most important Polish periodicals of the last 30 years related to mathematics education. This period coincided with many political transformations that significantly influenced views on education in Poland. After the collapse of the Warsaw Pact, the institutions of a democratic state had to be rebuilt from scratch. The social climate was conducive to change, so there was an opportunity for a fundamental reconstruction of the educational system. The present work shows to what extent the changes in mathematics education were reflected in the journals of that time.

Ewa Swoboda

ewa.swoboda@pwste.edu.pl

1 The State Higher School of Technology and Economics in Jarosław, Jarosław, Poland

2 The School of Education at the Polish-American Freedom Foundation and the University of Warsaw, Warsaw, Poland

3 The Maria Grzegorzewska University, Warsaw, Poland
The paper covers characteristics of particular journals, their main goals, and the topics they focused on. However, our main focus was to analyse whether the editorial boards of those journals intended to join the discussions regarding proposed and implemented changes as well as how they did so. We aimed to investigate whether Poland's opening to Western-European and American tendencies influenced educational views on shaping new generations. Tracking changes in mathematics education and observing them through the content of the journals mentioned, is the main focus of the present work. The international reader may be interested not only in the process of reforming mathematics education itself, but also in the footprint of this process left in mathematics education periodicals. Similar phenomena can be observed all over the world. By comparing different countries in this respect, it is possible to see the universal factors driving changes in mathematics education. Perhaps it is also possible to determine the specific factors which motivated the changes which took place in the countries of the post-Soviet bloc.

The paper continues the line of research on periodicals which is quite popular at present (Dąbkowska, 2019; De Bock \& Vanpaemel, 2015; Dubiel, 1989; Duda, 2011; 
Table 1 Polish mathematic education periodicals

\begin{tabular}{|c|c|c|c|c|c|}
\hline \multicolumn{3}{|c|}{ Journals established before 1990} & \multicolumn{3}{|l|}{ Journals established after 1990} \\
\hline Title & Year of founding & Periods of existence & Title & Year of founding & Periods of existence \\
\hline Wiadomości Matematyczne, & 1897 & $\begin{array}{l}\text { 1897-1939 } \\
1955-\text { till now }\end{array}$ & $\mathrm{NiM}$ & 1992 & 1992-2006 \\
\hline $\begin{array}{l}\text { Matematyka. Czasopismo } \\
\text { dla nauczycieli }\end{array}$ & 1948 & 1948 till now & $\begin{array}{l}\text { Biuletyn Studiów Nauczyciel- } \\
\text { skich }\end{array}$ & 1992 & 1992-2005 \\
\hline Dydaktyka Matematyki & 1982 & 1982 till now & Gradient-Kufer matematyków & 1992 & 1992-2001 \\
\hline & & & Matematyka w Szkole & 1999 & 1999-2015 \\
\hline
\end{tabular}

Furinghetti \& Somaglia, 2018; Preveraud, 2013). Periodicals represent the situation, discussions, and changes which characterize the period in question. In turbulent years of reform journals are the platform where options and changes are debated. Therefore, by studying journals we can get a picture of both the reform and of the forces opposing it. In Poland, such a broad debate took place in the pages of popular dailies (such as Gazeta Wyborcza, 1999), which were mainly focused on other societal problems, as educational changes were taking place simultaneously with many other important reforms (Karpiński et al., 2020). Focusing on a selected type of periodical means that additional elements must be taken into account, such as the history of the periodical, its permanent structure, and its specific audience.

\section{Methodology}

The choice of titles of publications that have been analyzed is the result of a compromise between the desire to present the largest spectrum of journals as possible and the need to focus on a few of them for an in-depth analysis. Such a compromise meant that we treated the period prior to 1990 very superficially, despite the importance of journals existing at that time. For instance, an important periodical, Młody Technik [Young Technician], which had a mathematical column (Duda, 2019) is not discussed at all. Some important publications from the beginning of the twenty-first century are also not mentioned (such as Annales Universitatis Paedagogicae Cracoviensis. Studia ad Didacticam Mathematicae Pertinentia, a journal that focuses on mathematics education research at the university level) because the short period of their existence makes it difficult to track changes in their profiles.

When deciding on the choice of periodicals, we analyzed the content of many available ones in terms of their response to changes taking place in mathematics education. As a result, some important journals with a long tradition and great recognition among mathematicians, teachers, and students were not included in our analysis because they did not respond substantially to new educational trends. We focused our overview on a few selected journals that, in our opinion, best reflect the attitude of the society to changes in education. ${ }^{1}$

Journals that shaped Polish mathematics education during the last 30 years varied significantly: some were targeted towards academia and others to teachers and parents. They were also published in different periods. Some were created in the late nineteenth century or just after the Second World War and are published to this day. Among those that we analyzed, many arose out of a clear need-as a reaction to changes taking place in education. The following table presents their titles along with the date of their creation and operation (Table 1).

While analyzing the periodicals, we tried to answer the following questions:

1. to what extent did social changes influence the content and structure of these journals?

2. to what extent did they respond to educational reforms taking place in Poland?

To address these goals a thorough comparative analysis of the journals was employed. Specifically, the following information was considered:

- A short history of the journal.

- The goals behind the creation of the journal.

- The main group of authors.

- The journal's structure as well as changes to it caused by the new political and social situation.

- Reaction to ongoing educational reforms.

\footnotetext{
1 Just to name a few more periodicals that have been omitted: Delta, the monthly journal addressed to high school students interested in mathematics, has been published since January 1974 as a joint cooperative of the Polish Mathematical Society and the Polish Physical Society, and Matematyka-Spoteczeństwo-Nauczanie [MathematicsSociety-Teaching] was published under this title between 1987 and 2013 and, since 2014, under a new name: Matematyka Pogladowa [Explanatory Mathematics].
} 
In order to facilitate the tracking of changes in relation to the last two points, articles from selected journals were classified. The major groups were identified in the process of the analysis of the content and were wide enough to be applied to various journals (with minor modifications). The categories were as follows:

1. Scientific-Popular (publications on mathematics, articles on the history of mathematics).

2. Essays on mathematics teaching.

3. Teaching methods.

4. Mathematics Problems.

5. Other (special occasions, reports and bibliography, chronicles, correspondence).

6. New technologies and IT in mathematics teaching.

7. (Explanation of) New curriculum.

\section{Background}

\subsection{On mathematics education in Poland from 1945 to 1989}

From 1945 up to the collapse of the socialist system in the 1980s, all intellectual achievements had to be subordinated to communist ideas. Accordingly, this period had its peculiarities, not only the economic ones, but also social, cultural, scientific, and educational. Primary and secondary education levels were the first ones to undergo changes (Musiał, 1918). Mathematics was treated as an essential subject used to support a 'scientific world view', as well as to build a theoretical base for technical subjects, which were to undergo exponential development. The ideology affected the teaching style and educational structure as well. A teacher-centered approach was dominant; teachers had to obey very strict timelines specifying when and how long to focus on particular issues, and an individual approach was discouraged (Karpiński et al., 2020).

Despite strong indoctrination, the methods of teaching mathematics reflected the changes taking place in Europe. Up to the $90 \mathrm{~s}$, we can distinguish three reform waves. The first one took place in 1960-1970. 'New Math' had its Polish equivalent, inspired by the work of a scientific group led by Zofia Krygowska. During the second wave of reforms (1970-1980), the main slogan was the implementation of the so-called 'mathematics for all' movement. Its implementation started in 1975 , but soon after that socioeconomic movements started to dominate and ultimately caused strikes and served as a basis for creating the Trade Union 'Solidarność' [Solidarity] on November 10, 1980. The reaction of the ruling government was to declare martial law in Poland on the 13th of December, 1981, across the whole country. Between 1980 and 1990, regardless of the educational reforms spreading through the whole continent, evidence-based discussion or reflection on education was impossible in Poland. During the martial law period, very strong censorship functioned, which made it impossible to express one's views freely. ${ }^{2}$ Even though martial law was abolished in 1983, the period up to 1990 did not see much education system reconstruction. The third wave of reforms consisted mostly of ill-judged, half-baked decisions which were undertaken to modify curriculum (Wiadomości Matematyczne, 1986, pp. 190-191). An open discussion on proposed changes became possible only from 1984. At the end of this period, people involved in mathematics education realized the urgent need for radical changes.

\subsection{Reforms of the education system since 1989}

After 1990, Poland became independent; many changes happened in all spheres including mathematics education. On September 12, 1990, the Higher Education Act was passed, which became the first comprehensive document in the postcommunist era providing basic legal regulations (Journal of Laws, 1990, No. 65 item 385). From September 1, 1992, a document titled 'Minimum Curriculum for Elementary and Secondary Schools' was in force in Polish schools (Decree No. 23 of the Minister of National Education of August 18, 1992). The adoption of this document allowed teachers to choose a study program from several programs approved for use in schools.

In May 1998, the Ministry of National Education presented its Reform of the Education System. The first stage, which started in 1999, concerned mainly the structure of the education system, where-among other changes-schools conforming to the more advanced form of secondary education, gymnasia, were created. Still, the Reform also covered vital recommendations on changes in teaching style, namely, a departure from the transmissive style of teaching and, instead, a use of individualized teaching based on the idea of cognitive constructivism.

\subsection{A few words about history of pedagogical periodicals in Poland}

The beginnings of the pedagogical periodical in Poland date to the first half of the nineteenth century (Dormus, 2017). During this period, the years of Poland's relative independence were intertwined with years of captivity. The period

\footnotetext{
2 After the declaration of martial law, the catalog of works subject to censorship included, among others, scientific and didactic publications of universities, Polish Academy of Sciences publications, independent research and teaching institution publications, as well as printed matter of these institutions used to collect data for research purposes (Bagieńska-Masiota, 2014, p. 193).
} 
from 1865 to 1915 was of significant importance for the periodicals, when after years of stagnation caused by the closure of Polish universities, Polish research centers began to reappear (Duda, 2011). In addition to their scientific function, they were a manifesto of Polishness and an attempt to mark independence. One of the initiatives undertaken by scientists was the creation of magazines, such as the magazine published by the Main School in Warsaw: Reports on Polish Scientific Literature in the Field of Mathematics and Natural Sciences (Warsaw 1882-1885), containing information about publications in Polish from the fields listed in its title. These works were still scarce, and textbooks, popular articles, and annual gymnasium reports prevailed (Duda, 2011).

One noteworthy thing was the appearance of magazines addressed only to mathematics teachers (often mathematics and physics). The first was the Wektor [Vector] magazine, published from 1911 to 1918. Among the contributors to the magazine were many excellent Polish mathematicians, such as O. Nikodym, J. Puzyna, W. Sierpiński, and H. Steinhaus (Dubiel, 1989, p. 34).

\section{Mathematic education periodicals-their role in implementation of educational reform}

\subsection{Period of reforms: short-lived journals}

A characteristic tendency reflecting the mood of times of change was the creation of new magazines, which were to be forums for sharing views on teaching mathematics. It turns out, however, that the journals created after 1990 had quite a short lifespan.

\subsubsection{NiM - Nauczyciele i Matematyka [T\&M - Teachers and Mathematics]}

After the transformation in 1989, Polish people felt that making a change in their country was possible. Many teachers decided to become involved in education system reform. This enthusiasm was the basis for establishing the Association of Mathematics Teachers in 1991, which is active to this day. The creation of the AMT was the result of personal contacts between Wacław Zawadowski, a professor at Warsaw University, and Jan Potworowski from Brunel University in London. These led to the first teachers 'visits to England as part of the TEMPUS program (Karpiński et al., 2020). The AMT's goal is to cooperate in order to provide mathematics teaching quality improvements in Poland (http://www.snm. edu.pl/p/blog-page.html). The core activity of the Association is to give workshops and to organize conferences for teachers of mathematics. Between 1991 and 2020, almost
30 national conferences (and many more regional ones) held by the AMT took place.

The Association also published a quarterly, NiM - Nauczyciele i Matematyka, aimed at teachers of mathematics working in schools of all levels. It was an internal journal, serving as a means of communication for AMT members. Issue number 1 was compiled in spring of 1992. Marek Legutko was the first editor-in-chief of NiM. For all the members the quarterly was free (covered by their membership fees); readers outside of the Association could buy a subscription.

The first issue opened with information on the Founding Convention and the first Annual General Meeting of the Association of Mathematics Teachers. Some of the articles published there covered the so-called 'minimum curriculum' developed in 1991 for mathematics and other subjects. Its draft, prepared by the Ministry of Education, was presented there, as well as the position of the Krakow branch of the AMT on the modernization of the curriculum. Examples of similar documents from the United Kingdom were published, too. Other articles covered teaching of mathematics: there were specific exercises or problems ready to be presented to a class. Some of them proved that using calculators at school did not mean giving up thinking. A typical issue usually comprised articles on the following:

- teaching mathematics-e.g., How do I Teach series, where different teaching styles were described, such as 'Standing in the Queue' (Turnau, 1993), and 'High Five' (Malicki, 1994);

- using computers and normal and graphing calculators at school-'Probability \& Bridge \& Graphing Calculator' (Pawłowski, 1993);

- examples of specific mathematical problems solved at school—e.g.. 'Algebra in Fractions' (Niedośpiał, 1994).

Many of those articles began as speeches by the authors given at conferences organized by the AMT. In the quarterly one could also find analyses of documents on curricular changes, reports from teachers' visits abroad, exercises used in mathematical competitions, and subject matter book reviews. Both methodologists and active teachers wrote articles published in the quarterly. The most common names among authors were Jan Baranowski, (co-founder of the AMT), Marek Legutko (the first editor-in-chief of T\&M, and author of textbooks on mathematics), Krzysztof Mostowski (co-founder of AMT, and author of many texts about using calculators in teaching mathematics), Bronisław Pabich (CABRI popularizer), Klemens Stróżyński (an expert of the Ministry of National Education for school textbooks,), Stefan Turnau (the closest collaborator of Z. Krygowska), and Wacław Zawadowski (the first President of the AMT). 
The last issue (no. 60) of the NiM was published in 2006. Its circulation was 1500; the total number of all mathematics teachers in Poland at that time was about 30,000.

\subsubsection{Biuletyn Studiów Nauczycielskich [Teachers' Colleges Bulletin]}

In 1990, the Ministry of National Education established a 3-year teachers' college, a new organizational form of professional teacher training. The possibility of implementing new ideas was ensured by participation in the European Union's TEMPUS assistance programs (Trans-European Mobility Program for University Studies), of which Poland had been a beneficiary since 1990 . Teachers working in the 3 -year colleges honed their new qualifications by participating in these projects. The necessity of sharing, and willingness to share new experiences, resulted in the creation of a new magazine. Biuletyn Studiów Nauczycielskich was created in 1992 in Szczytno (where one of the first teachers' colleges was founded). The texts, written by enthusiasts, informed about training and workshops as well as reporting on conferences and events organized by colleges. According to Klus-Stańska (2005), the topics discussed there could contribute to '.. changing the way of thinking about teacher education, reconstructing your own theory, or at least making it more aware and prone to personal reflection' (p. 34). The existence of the journal ended in 2005 with the ministerial decision to close the teachers' colleges.

\subsubsection{Matematyka w Szkole [Mathematics at School]}

The main publication that aimed to prepare teachers for the tasks set before them by the new reforms was the journal Matematyka $w$ Szkole. The idea of setting up a new journal was put forward by the community involved with the Gdańskie Wydawnictwo Oświatowe Publishing House (GWO). The first issue was published in 1999. It was a special moment, as in September 1999 the education reform took effect, restructuring both the school system (gymnasia were introduced) and the curricula.

Within a couple of years, GWO gathered a community of specialists developing a new way of teaching mathematics. The aim was not only to develop a theoretical concept of improvement, but to implement a true transformation in schools. Those involved worked to convince teachers to change their methods. The teaching style of that time required a high number of changes: proposing all of them at once might have been considered too revolutionary, and, therefore, it might have been rejected. This is the reasonas a result of the discussion of specialists cooperating with GWO (Karpiński's personal experience) — that the plan for implementation of the new teaching style was proposed as follows:
1. The concepts which are taught should not be presented to teachers as in a scientific paper, but with detailed and comprehensive education materials.

2. All key new ideas should be debated among the highest possible number of teachers and tested at school.

3. If some ideas are rejected or difficulties in their implementation arise, they should be amended.

At that moment of rapid and thorough changes, which were problematic for many teachers, the first issues of Matematyka $w$ Szkole were published. The main goal of the journal was to provide teachers with support, reliable information, and working materials concerning the reform. The editorial board wrote in the premiere issue of the Matematyka w Szkole:

The following school year will inaugurate the implementation of the education reform. [...] Teachers need to be aware of the ongoing changes; the present bimonthly will provide them with information on this subject. Mathematics at School is a journal focused on the practical approach. Each of us either works or worked at school, so we have first-hand experience on the education system issues and teachers' needs. The majority of the content will include materials directly applicable at your place of work (Matematyka w Szkole, spring 1999). ${ }^{3}$

Matematyka w Szkole was published from 1999 to 2015. The journal was available solely by subscription. The circulation of the first issues was 2500 copies, equalling about $10 \%$ of all the mathematics teachers in primary and middle schools.

The structure of sections of the journal, determined by the Editorial Board, did not vary much throughout the years. The core sections were as follows: Education, Cover Story, Teaching Mathematics, Materials, and From the Last Desk. They always appeared in this order, so we follow this order in our description of the sections.

The Education section always covered topics related to the whole education system, not only mathematics. This is where descriptions, analyses, and opinions on the changes in curricula were published. It also covered the interpretation of the outcome of international studies such as PISA, TiMSS, PIAAC, or TEDS-M. This section also included articles on teaching abroad, often presented from the point of view of foreign teachers. One of the examples is a series of articles titled Letters from Antwerp by Jacek Lech, a Polish teacher who taught mathematics in an international school in Belgium for 4 years.

\footnotetext{
$\overline{3}$ All translations from Polish are by the authors.
} 
Table 2 Summary of topics covered in articles published in Matematyka w Szkole in selected years

\begin{tabular}{lllllllll}
\hline Year & \multicolumn{2}{l}{ Type of article } & & & & & \multicolumn{1}{c}{$\begin{array}{c}\text { Number } \\
\text { of issues }\end{array}$} \\
\cline { 2 - 7 } & 1 & 2 & 3 & 4 & 5 & 6 & 7 & \\
\hline $1999 / 2000$ & 7 & 18 & 40 & 30 & 11 & 3 & 18 & 6 \\
$2002 / 2003$ & 14 & 18 & 71 & 42 & 12 & 6 & 35 & 9 \\
$2009 / 2010$ & 7 & 27 & 39 & 25 & 9 & 2 & 18 & 8 \\
\hline
\end{tabular}

Key to columns: (1) Scientific-popular (2) Essays on mathematics teaching (3) Teaching methods 4) Mathematical problems (5) Other (6) New technologies and IT in mathematics teaching (7) New curriculum
The Cover Story section was always dedicated to a chosen aspect of teaching mathematics and it included a number of articles on the same subject. Here are a few examples of cover stories:

- Mathematics Is Everywhere (No. 3/2000)—unconventional and challenging ways of using mathematics available even for primary school pupils;

- Geometric Imagination (No. 15/2002)_practical class ideas to develop this skill;

- Understanding and Reasoning (No. 62/2011)-how to teach it.

These three examples are a good illustration of the direction of changes in mathematics education promoted by the journal's editorial staff. The differences between teaching mathematics before 1989 and the teaching proposed by the reforms can best be seen by examining the approaches toward teaching mathematics in the lower grades. There were many changes in how those students were taught applications of mathematics, and in fostering the ability to conduct mathematical reasoning, as well as in how teachers attempted to shape their intuition.

The section Teaching Mathematics was the core of each issue. It included a great variety of articles. The following examples illustrate the profile of this section:

Buniecka (2001), in her article ' $\pi^{2} \approx \mathrm{g}$. Where Does a Meter Come from?', explained the relationship between the acceleration caused by gravity and $\pi$ squared, how those two values are related to a second and a meter, and what a pendulum has to do with the whole situation.

Piecewska-Łoś (2008-2015), The Thirteen Books-a series of articles on Euclid's Elements. The 13 books of Euclid were analyzed from the point of view of a modern teacher of mathematics.

In the Materials section teachers could find class scenarios, handouts, tests for specific areas, competition tasks, mock exams, etc.

From the Last Desk always included only one text-a humorous opinion piece. It usually covered current absurdities such as oddities of school administration or educational examples of innumerate journalists and politicians.

This journal kept a quite consistent profile throughout the 16 years of its existence. The journal varied from others discussed in the present paper due to the style and register of published articles. They were not scientific. The articles were understandable to teachers and, above all, they were brief. They did not exceed five pages, and were usually 2-3 pages in length. This is why the final product resembled an illustrated weekly rather than a journal for professionals only (Table 2).

\subsubsection{Gradient - Kufer matematyków [Gradient - Mathematics Trunk]}

There were, however, journals that clearly distanced themselves from the changes put forward by the Ministry. There was visible resistance to the changes, as displayed in Gradient - Kufer matematyków, a journal published by a large group of mathematicians. The journal has been published since 1992 by the Foundation for the Development of Polish Mathematics. The journal's editorial team has included Jerzy Norwa, Kazimierz Cegiełka, Jerzy Przyjemski, Karol Szymański, and Jacek Uryga. They were mathematicians (mostly with PhDs in mathematics) related to various of Warsaw's academic centres. Among the editorial staff there were authors of very popular textbooks for secondary school mathematics. These textbooks were written in the transmissive style - the mathematical content was presented in a very orderly manner, and the students' activity was mainly limited to the application of theory while solving problems. It is quite significant that these scientists clearly separated themselves from this stream concerning the issue of implementation of the reforms. It is visible both in the 'Manifesto' formulated in the first issue, and in the content of the subsequent numbers:

For many years, the whole society, including teachers, and even students and their parents have expressed dissatisfaction in various ways and do not approve of the current state of teaching.... We have been working on improving this teaching for many, many years. More aware members of our society - and there are many mathematicians among them-postulate not only more rational teaching - in the sense that knowledge and mathematical skills learned from school are more operational than current skills - but also that the teaching system itself is more economical, more effec- 
tive and more attractive in the broad sense (Gradient, 1992, pp. 3-4).

One gets the impression that the creators of Gradient felt that it was their obligation to share their experiences and their knowledge - both in the area of teaching methods as well as in expanding the mathematical knowledge of active teachers. They wanted at any cost to prevent lowering the level of mathematical knowledge that was supposed to apply in schools. Indeed, among the proposals that appeared in the journal were many interesting materials for working with students who might be future mathematics teachers. These materials showed particular sections of mathematics in an interesting way, but these were issues in the field of theoretical mathematics, distant from what could directly affect the professional teacher's work, and something very far from the average schoolteacher's interest. An example would be the work of Andrzej Schnizel (1992) 'Progress in Number Theory in 1989-1992'. Presumably, publishing articles on theoretical issues was aimed at broadening the scientific knowledge of teachers. This approach was an expression of the conviction that only a teacher with a wide knowledge can be a good teacher. The permanent, significant item of each issue was a set of competition tasks from various levels of education, including International Mathematical Olympiads. A clear reluctance when it came to change in Polish schooling, which was inspired by foreign influence, can be confirmed by the following paragraph, also from the Gradient's Manifesto:

Gradient ... it will also invite outstanding (Polish above all) mathematicians to cooperate, and will also use foreign sources. Of the latter, not very often and not too much; nevertheless. Poles are not geese ${ }^{4}$..... And in addition ... rich methodical literature exists. What's happening abroad-it's worth it and you even need to know, but ... this does not mean uncritically transferring it to our own, Polish, not the worst, ground. (1992, p. 5)

However, the magazine did not last long. The last issue was released in 2001, and the decision to finish its publication was made by the Foundation's authorities.

\footnotetext{
4 This is a reference to the popular epigram of Mikolaj Rej (15051569), the first poet who began to write in Polish rather than in Latin. The epigram says that Poles do not goose, that they have their own language.
}

\subsection{Pedagogical periodicals established before 1990 and their impact on mathematics education through today}

\subsubsection{Wiadomości Matematyczne [Mathematica Messages]}

In 1897 there appeared a magazine which was entirely devoted to mathematical discipline and mathematicians. It was Wiadomości Matematyczne, created by Samuel Dickstein (a Polish mathematician, professor at the University of Warsaw, encyclopedist and historian of science). Before the outbreak of World War II, 47 volumes were published (Fick, 2018). The break in the functioning of Wiadomości Matematyczne lasted until 1955, when the Polish Mathematical Society decided to revert to its tradition and to resume publication of this magazine (Duda, 1997). Popular articles about mathematics theory as well as information about conferences and other mathematical events were to appear in it.

This journal, with its long history, was supposed to constitute a forum for the exchange of scientific thought and any information valuable for the mathematics community. Minor scientific works from many mathematical areas, including popular science articles on the history of mathematics (Polish, mainly) were published there. The journal also informed its readers about important events, such as conferences and anniversaries. Other types of offerings were biographies and contributions of deceased scientists as well as of persons who had just received professorships. Also, the winners of various contests organized by the Polish Mathematical Society were presented. Reviews of new academic textbooks were popular, and authors debated amongst each other or reacted to reviews or to the content of other articles. There was also a humour and literature section, with loose reflections on mathematics, and even poems about the discipline.

Issues related to education were never a major concern of the editorial board. Still, the first post-war issue included articles on education, but they concerned universities of technology (Wrona, 1955).

After WW II, the first wave of education reforms in Poland took place from 1960 to 1970. At its beginning, some of the articles published in Wiadomości Matematyc$z n e$ reacted to this wave. In almost each issue of Wiadomości there was an article about teaching mathematics, mainly thanks to the work of Z. Krygowska. Choquet's views (1960) were published as well as reports from conferences dedicated to new teaching styles (Krygowska, 1954), but later, the reforms were rather ignored. Between 1960 and 1970 in Wiadomości Matematyczne only one article directly referred to education reform (Nowecki, 1967).

Between 1970-1980 Wiadomości Matematyczne joined the national debate on mathematics education. The journal published many critical articles, in which the authors warned about the overload of new content and hasty excitement over 
Table 3 The content published in Wiadomości Matematyczne in years 1960-2019

\begin{tabular}{llllllll}
\hline Years & \multicolumn{3}{l}{ Type of article } & & & \multicolumn{2}{c}{$\begin{array}{l}\text { Number } \\
\text { of issues }\end{array}$} \\
\cline { 2 - 6 } & 1 & 2 & 3 & 4 & 5 & 6 & 17 \\
\hline $1960-1969$ & 139 & 20 & 1 & 18 & 231 & - & 10 \\
$1971-1980$ & 119 & 26 & 4 & 7 & 265 & - & 10 \\
$1981-1988$ & 75 & 19 & - & 1 & 167 & 2 & 9 \\
$1990-2000$ & 108 & 3 & - & 10 & 184 & - & 10 \\
$2001-2010$ & 81 & 1 & - & - & 177 & - & 16 \\
$2011-2019$ & 70 & 3 & - & - & 356 & - & \\
\hline
\end{tabular}

Key to columns: (1) Scientific-popular, (2) Essays on mathematics teaching, (3) Teaching methods (4) Mathematics problems (5) Other (6) New technologies in teaching mathematics new trends, which were to be implemented by unprepared teachers (Karpiński et al., 2020).

The next reform, taking place from 1980 to 1990 again stirred a debate. Thus, it is hardly surprising that the debate over the proposed changes to the approach to teaching mathematics also took place in the pages of the Wiadomości Matematyczne. Sometimes these voices were very radical, calling for a return to the approach in the early twentieth century, as in the opinion presented below:

... The anachronism of old syllabi is not as frightening as the progressives suggest.... The canon of elementary school mathematics remains unchanged. A school must teach how to count. Also 'applying psychology to the development of mathematical concepts' cannot replace the great and extremely educational satisfaction that a child gains from the ability to count effectively and the resulting opportunities to participate in adult life (Burnat, 1987, p. 327)

Regardless of such opinions, it was clear that a thorough analysis of the state of mathematics education in Poland was necessary and required. The first results were announced in May 1988; however, the final text appeared two years later (Semadeni, 1990 ) - the journal was not published in 1989. Unfortunately, it was only one of three articles concerning mathematics education published in Wiadomości Matematyczne between 1990 and 2000 and one of two related to changes in education. The other one was related to the formula of the new matura examination planned for 2002, where mathematics would be obligatory again (Ombach, 1997). During the period 2001-2019, the matter of education was raised only 4 times. It was usually mentioned in a critical tone, and the articles did not always concern Poland, e.g., the views of Vladimir I. Arnold (2001). They expressed their nostalgia for the past; the main source of their dissatisfaction was the curriculum, as is visible in the following quotation:

In the summer of 1989, when the pot of political, social and economic changes almost exploded, I went to a second-hand bookshop and bought some rare mathematical textbooks from the beginning of the 20th century. Later on I gave out most of them as gifts to the distinguished authors of the education and economic reform in those turbulent times (Turski, 2016, p. 69).

The table below (Table 3) presents types of articles published in Wiadomości Matematyczne in the years 1960-2019.

Table 3 presents the direction in which Wiadomości Matematyczne evolved in a somewhat interesting way. Even though the first issues of the journal were open not only to mathematical topics (column 1), but also to educational ones (column 2) or methodological ones (columns 3 and 4), after the shift in the political system the thematic scope narrowed significantly. One might assume that the interest of the editorial board in producing a mathematical publication slowly decreased. Education was no longer a debate subject in Wiadomości Matematyczne. There was also no interest in new technologies that could be used in teaching mathematics (column 6). This trend can be related to the visible isolation which was experienced by the members of both communities, theorists and educators. This is an alarming phenomenon. Statements on, for instance, the overall results of the matura exam (in which mathematics is an obligatory subject), or the global competence assessment, would probably attract members of both feuding communities and could even form a base for much needed understanding and acceptance.

\subsubsection{Matematyka. Czasopismo dla nauczycieli [Mathematics. Teacher's Journal]}

Soon after 1945, despite legal and political agreements on the shape of Polish education, a journal addressed to teachers of all educational levels and all types of schools was established. It was Matematyka. Czasopismo dla nauczycieli. The first issue was published in 1948. The periodical was founded by Bolesław Iwaszkiewicz, who as a ministerial employee, in the years before World War II, dealt with matters related to education, and after the war was associated 
with universities in Wrocław. Wroclaw's Universities promoted strictly scientific activity, but the journal Matematyka saw the light of day (Duda, 2011).

The journal served many purposes at the beginning of its operation. It supported teachers by supplementing their substantial knowledge, provided teaching materials and novelties, and enabled consolidation of the mathematics teaching community. During the first years of its operation, one could find many names distinguished in both Polish and world mathematics among the authors publishing in Matematyka. For example, in volume 1(29) 1954, one can find the work of Wacław Sierpinski, 1954 Stefan Straszewicz, 1954 and Zofia Krygowska. The creators of the magazine declared that "The mission of Mathematics is to support teachers at all stages of the educational path by publishing analyses and explanations of tasks" (p. 8). The editors announced that the journal would publish the following:

Articles informing in a way that does not require special preparation about the scientific problems of modern mathematics - essays on subjects that go beyond the traditional circle of school mathematics .... applications of mathematics in many fields of natural sciences ... applications of mathematics to many fields of natural sciences ... articles illustrating the history of mathematics, its current state, development of mathematical concepts, and figures of great mathematicians (Fick, 2018).

It seems that such a variety of topics as well as a wide range of levels (from issues of mathematics teaching in primary school to academic issues) was accepted by the magazine's recipients at that time.

The new political reality (brought on by the collapse of the Warsaw Pact) had a significant impact on the perception of Matematyka. The editors of the magazine returned to Wrocław in the early 1990s. Agnieszka WojciechowskaWaszkiewicz became the editor-in-chief. The editorial committee still included several researchers from the University of Wrocław, but also popular mathematicians known in Poland, authors of school textbooks from various educational levels, as well as scientists treating didactics of mathematics as a scientific discipline.

Matematyka changed its graphic design, which was visible mainly on the cover. The size and content remained unchanged. Many issues have been preserved, and they contained information from the history of mathematics, philosophical and scientific texts, materials concerning teaching methods, teaching advice, information about the legal basis of teacher's work, tasks for mathematical circles, and tasks to inspire competitions. There were also novel sections that attempted to broaden issues, an example of which was Computer Science at School, a section that appeared sporadically and was devoted to the philosophy and teaching of computer science, and Mister-Mat, a Polish-English illustrated dictionary of school mathematical terms with exercises.

The 50th anniversary of the journal became an occasion to summarize. The majority of voices praised the level and subject of the articles (Pogoda, 1999; Wuczyńska, 1999), but there were also critical voices that spoke of an overly idealistic approach: "some articles cause confusion, suggesting that various very difficult things can be done in class or in extracurricular activities, especially if such a text is printed under the heading "Teaching mathematics" (Wojciechowska, 1999, p. 260). The teachers' opinions are also interesting; they emphasized that they often used the magazine but stated that "there were many theoretical articles in Matematyka, written in difficult language. Reading such articles required a lot of effort on the part of the teacher and often referring to other sources to understand the content of the article" (Zając, 1999, p. 315). They also suggested that the journal should contain "more examples of didactic solutions, ... more information about future reform, about skills and new methods" (Zając, 1999, p. 317). It can be assumed that these suggestions were implemented to some extent in the following years.

The language in which the articles were written changed, which was certainly a 'marketing ploy'-popular articles were written in a light enough language, whereas mathematical articles focused on topics oscillating around mathematical curiosities like Cryptarithms (Bednarek, 1999). Also, the magazine became a platform for informing teachers about planned (and occurring) changes in education at every level. For example, in issue 4(278) 1999, there was one whole section entitled Education Reform, containing reflections and comments related to the next wave of reform being prepared, discussing the proposals of the core curriculum for the gymnasium, and even presenting articles on textbooks as well as various other school publications, which at that time began to appear like mushrooms after rain. Among other things, Marek Legutko, one of the leaders of the reform, published his opinion several times (Legutko, 1999). One of his articles, presented under the common title Reform Ahead, begins as follows:

The New Core Curriculum for Mathematics (signed on February 15, 1999) should show the position of the Ministry of National Education regarding the questions: Why do we teach mathematics? What should we teach, what should we require? How should we teach? Without this, it is difficult to talk about establishing a clear educational standard in the Foundations. Unfortunately, the core curriculum for mathematics does not meet these obvious demands. (Legutko, 1999, p. 230)

In this section, which existed for several years, both teachers and those working in the didactics of mathematics presented their points of view (e.g., 'How to Keep a Cool 
Table 4 The summary of topics covered in articles published in Matematyka in selected years

\begin{tabular}{llllllll}
\hline Year & \multicolumn{2}{l}{ Type of article } & & & \multicolumn{2}{c}{$\begin{array}{l}\text { Number } \\
\text { of issues }\end{array}$} \\
\cline { 2 - 6 } & 1 & 2 & 3 & 4 & 5 & 6 & 6 \\
\hline 1954 & 23 & 24 & 19 & 24 & 33 & - & 6 \\
1978 & 10 & 48 & - & 37 & 25 & - & 6 \\
1988 & 10 & 20 & - & 55 & 6 & - & 6 \\
1998 & 23 & 23 & - & 33 & 55 & - & 11 \\
2010 & 13 & 50 & 37 & 22 & 33 & 8 & 6 \\
2019 & 12 & 23 & 41 & - & - & 8 \\
\hline
\end{tabular}

Key to columns: (1) Scientific-popular (2) Essays on mathematics teaching (3) Teaching methods (4) Mathematical problems (5) Other (6) New technologies and IT in mathematics teaching.
Head?' by Turnau, 2003). Another example of the opening of the new recommended style of teachers' work was a section called, Chronicles, telling about implemented or planned actions aimed at improving the qualifications of teachers. For example, the section gave information on the open workshops for teachers organized by leaders of international TEMPUS projects and reports on the conferences of the newly created Association of Mathematics Teachers. Sometimes these descriptions were very extensive, such as the report written by Agata Hoffman (1992) about an action conducted in Wroclaw by Englishmen Jan Potworowski, Tony Brown, and David Cain, published under the slogan For you, for children, for mathematics.

Since 2014, the journal's publisher has been Forum Media Polska in Poznań. Slowly, it began to move away from presenting academic issues, focusing more on providing broad methodical and practical knowledge. Editors try to include the section titled Topic of the Issue in each magazine, which is a discussion of the most current and interesting problem related to the work of a mathematics teacher. They offer materials directly suggesting ways to check knowledge, to be used during lessons. The materials are ready for photocopying for the classroom or for use in extracurricular activities. Very popular was the section Ideas for Lessons - a forum for exchanging original ideas between teachers. Instead of scientific articles, a section offering hints focused on teacher development was created. The materials there were diverse-from curiosities derived from quite narrow branches of mathematics to broadly applicable tips on methods.

However, the magazine has not changed its eclectic character. It is still targeted at teachers working at all educational levels and in different types of schools.

Below is a simple summary (Table 4) illustrating changes in content of the journal in the chosen years.

This overview can be summarized as follows: During their first decades the journal was mainly concerned with improving teachers' mathematical knowledge (scientific and popular scientific articles, essays on math teaching). The authors also strove to offer additional exercises for pupils, to promote mathematics competitions on various education levels, and to present unconventional solutions. The main goal at that time was to build a mathematics teachers' community so that its members could discuss current topics as well as share information on various events (conferences, meetings, school events) and on publications.

Right before 1989, providing scientific knowledge was not Matematyka's main goal, which can be explained by the fact that many mathematics teachers had higher education degrees (MA in mathematics). Taking care of talented students' development was extremely important: the journals published extra exercises for them (to be used in extracurricular classes). Methodological materials, such as class plans or ideas for introducing particular subjects were not published.

Some time about 1998, as the Polish education system was undergoing consecutive reforms, the journal published both popular scientific articles (mainly on historical perspectives) as well as ones concerning new mathematics teaching styles. The journal became a platform for exchanging comments and discussing.

Later on, the role of the journal changed significantly (in the twenty-first century). Popular scientific articles are still published, but in much lower numbers than before. Those materials are usually directed to students attending extracurricular classes, and not to teachers aiming to improve their mathematical competences. There has been a significant increase in publications offering teaching materials: class plans, handouts, tests. Supporting teachers with mobile applications and new technologies has been widely promoted in Matematyka. Interestingly, the journal 'transmits' the information, but the 'platform' function has disappeared; the readers no longer use it as means to share their comments and observations.

\subsubsection{Didactica Mathematicae}

The first issue was published in 1982 under the title Dydaktyka Matematyki (Didactics of Mathematics). Zofia Krygowska became the Editor-in-Chief, and the editorial team 
included her closest collaborators from Krakow, as well as those scientists who readily accepted the emergence and development of a new discipline. The journal was published as one of a series from the Polish Mathematical Society, and it was meant to boost the development of this new scientific discipline, mathematics education.

In the introduction to the first number of the periodical, the editorial committee described the nature of the publication as follows:

Dydaktyka Matematyki series is intended to promote theoretical analysis and empirical research developed in mathematics didactics in Poland. The Polish Mathematical Society addresses itself to everyone who is interested in the theoretical foundations of mathematical education and their practical applications.

... Didactics of mathematics is a new discipline at an early stage of its development (Dydaktyka Matematyki, 1, 1982).

The first issues contained papers that gave an international dimension to Polish didactics of mathematics. These were the works of the leading Polish mathematics educators. Among others, the first issue contained articles prepared by Zofia Krygowska (1982), Wanda Nowak (1982), Roman Duda (1982), and Zbigniew Semadeni (1982).

Krygowska's ambition was shaping the Polish scientific community by providing (via translations into Polish) works appearing in international magazines not available at that time in Poland, or via reprints of papers presented at international conferences and symposia. The journal contained extensive information on those international conferences, too.

In 1988 Krygowska died. Stefan Turnau, one of Krygowska's closest collaborators, tried to continue her editorial activities. However, the situation was not easy. Officially, Dydaktyka Matematyki operated under the aegis of the Polish Mathematical Society, but there was still no acceptance of didactics of mathematics as a scientific discipline by the Ministry of Science. The editors strove to balance, trying to broadly define the target group to which the magazine was to be addressed. It was very important to maintain the status of a scientific journal, subject to ministerial evaluation, because it in some way manifested the existence of the discipline. On the other hand, it was still important to post information about international congresses and conferences as well as present translations of significant works of foreigners. The editors also had a somewhat idealistic notion that the published papers would be read by active teachers, which is why they maintained Polish as the language of the publication (although essays were to have an English title and an abstract in English).

Actually, the magazine itself was highly valued in the Polish community. The sympathy of foreign scientists resulted in their agreement to give up their copyright and to translate their work into Polish. In this way, articles of the prominent authors such as Maurice Belanger (1990), Alan Bell (1992), Erich Wittmann (1993), Heinz Steinbring (1994), Annie Bessot (1996), Hejný (1997), Frantiśek Kurina (1998), Nad'a Stehliková (1999), and Jana Višňovská (2000) appeared in Dydaktyka Matematyki.

In 2007 series V changed its Polish name Dydaktyka Matematyki to the Latin name Didactica Mathematicae. The new political situation (opening borders and the possibility of direct participation in international conferences) forced a partial change of the periodical's regular features: reprints from other magazines or translations of conference speeches ceased to appear.

In 2012 the authorities of The Polish Mathematical Society appointed a new Editor-in-Chief: Ewa Swoboda. The new management of the magazine focused on extensive international cooperation. In addition to the local editorial office, a very strong international editorial board was established, to which leading researchers were invited not only from neighbouring countries and the former communist bloc, but also people from various parts of Europe, Israel, and America. None of the invited guests refused their membership; on the contrary, the invitations were received with great cordiality.

Didactica Mathematicae tried to keep up to date with the latest trends in teaching research. Its reaction to changes in Poland was rather more general and theoretical than practical.

\section{Conclusion}

In this paper we discussed changes in the most prominent Polish journals focused on mathematics teaching during the education reforms after 1989 in Poland. Hence, the analysis of the periodicals was focused mainly on finding an answer to the question: to what extent were changes in the approach to mathematical education in Poland, caused by political, economic and social developments, reflected in journals related to mathematics and its teaching?

Our analysis leads to the conclusion that journals, where the authors are mostly mathematics scientists or university lecturers, turned out to be indifferent to shifts in the educational system. Changes in schools' structure, curricula, examination systems, or technological development, did not much influence the content published there. In Wiadomomości Matematyczne, there is little trace of the turbulent changes taking place in the educational system and the challenges faced by teachers and pupils as a result. Delta and Matematyka-Społeczeństwo-Nauczanie, directed toward students in high schools and universities as well as everyone interested in mathematics, continued to operate without any 
reaction to the new trends, as mentioned in the Methodology section. The articles published there expanded vastly the material covered in high school and they broadened the knowledge of those keen to study science more deeply. This is how the mathematicians declared that education issues (apart from working with exceptionally talented pupils or those with much interest in the field) were not of much concern to them. Sometimes the mere declaration of changes provoked heated opposition, bordering on nostalgia for the past (see Gradient). As a result, the burden of discussing issues around the implementation of reforms was shouldered primarily by new (and a few existing) journals.

Education journals that were directed to teachers for decades constituted a platform for discussion of new ideas and teaching styles. They offered a place to exchange opposing views. However, this situation slowly ceased to apply. The two periodicals for teachers that we analyzed, Matematyka and Matematyka $w$ Szkole shaped a new approach to teaching. Matematyka was only partially devoted to the subject of changes in the core curriculum and the related change in the teacher's work style, while Matematyka $w$ Szkole fully subordinated its content to the support of reforms during their implementation.

Matematyka still has its regular group of readers, but this group is constantly shrinking. One of the reasons may beparadoxically — an attempt to modernize the form of writing and the style of articles. It seems that such an attempt, which mimics global trends in the other journals, does not appeal to the Polish audience. Archival issues have appeared on the journal's website, but only from issue 1 of 2014. An attempt to reach a larger audience is undoubtedly the goal of the journal not only in its printed form, but also via the online platform (https://czasopismomatematyka.pl/), where full access to articles is possible. The subscription to the magazine, however, is expensive, which can also be a barrier for teachers, who are accustomed to cheap (or even free) resources. There is also a noticeable lack of personal involvement of the teacher/readers; instead of joining discussions, readers look for ready-made materials for classes. It is possible that along with the digital development, the discussion has moved online. Unfortunately, it is dispersed in many websites, so that it is difficult to find one place where professional and opposing opinions on mathematics education are exchanged. For now, journals seem to have been irreplaceable in this matter.

It is difficult to define the place of the scientific periodical Didactica Mathematicae. This is related to the status of didactics as a discipline, which is still not recognized by the Ministry as a research field, and the voice of an ever-smaller group of scientists dealing with research about learning and teaching mathematics is not taken into account when making key educational decisions. The almost 40-year history of the journal and scientifically important publications of Polish and foreign authors referring to current world research issues still do not lead us to state that it has a significant impact on the shaping of educational policy related to teaching mathematics.

Open Access This article is licensed under a Creative Commons Attribution 4.0 International License, which permits use, sharing, adaptation, distribution and reproduction in any medium or format, as long as you give appropriate credit to the original author(s) and the source, provide a link to the Creative Commons licence, and indicate if changes were made. The images or other third party material in this article are included in the article's Creative Commons licence, unless indicated otherwise in a credit line to the material. If material is not included in the article's Creative Commons licence and your intended use is not permitted by statutory regulation or exceeds the permitted use, you will need to obtain permission directly from the copyright holder. To view a copy of this licence, visit http://creativecommons.org/licenses/by/4.0/.

\section{References}

Arnold, V. (2001). O nauczaniu matematyki [On teaching mathematics]. Wiadomości Matematyczne, 37, 17-26

Bagieńska-Masiota, A. (2014). Prawne podstawy cenzury prasy w okresie stanu wojennego w Polsce (1981-1983) [Legal basis for press censorship during the martial law period in Poland (19811983)]. Czasopismo prawno-historyczne, 66(2), Uniwersytet Adama Mickiewicza Poznań, 185-203.

Bednarek, W. (1999). Kryptarytmy [Cryptarithms]. Matematyka, 4(278), 206-207

Belanger, M. (1990). Błędy w rachunku arytmetycznym: badania i poglądy amerykańskie na przestrzeni stulecia [Errors in arithmetic computation: A century of American speculation]. Dydaktyka Matematyki, 12, 55-77

Bell, A. (1992). Systematyczne użycie konfliktu poznawczego w nauczaniu - trzy eksperymenty [The systematic use of cognitive conflict in teaching: Three experiments]. Dydaktyka Matematyki, 13,955

Bessot, A. (1996). Ramy teoretyczne dydaktyki matematyki we Francji [Theoretical frameworks of mathematics didactics in France]. Dydaktyka Matematyki, 18, 31-56

Buniecka, D. (2001). $\pi^{2} \approx \mathrm{g}$. Skąd się wziął metr? [ $\pi^{2} \approx \mathrm{g}$. Where does a meter come from?]. Matematyka $w$ Szkole, 10, 18-19

Burnat, M. (1987). Listy do Redakcji: Głos malkontenta, czyli jeszcze o programach matematyki [Letters to the Editor: The voice of dicsontent regarding mathematics programs]. Wiadomości Matematyczne, 27, 326-330

Choquet, G. (1960). Matematyka współczesna a nauczanie [Modern mathematics and education]. Wiadomości Matematyczne, 4, 43-57

Dąbkowska, E. (2019). Polish mathematics education periodicals from 1930 to 1950 . Doctoral dissertation, Columbia University. https:// academiccommons.columbia.edu/doi/10.7916/d8-82a7-h503.

De Bock, D., \& Vanpaemel, G. (2015). The Belgian journal Mathematica \& Paedagogia (1953-1974): A forum for the national and international scene in mathematics education. In E. Barbin, U. T. Jankvist, \& T. H. Kjeldsen (Eds.), History and epistemology in mathematics education: Proceedings of the Seventh European Summer University. (pp. 723-734). Aarhus University, Danish School of Education.

Decree No. 23 of the Minister of National Education of August 18. (1992). 
Dormus, K. (2017). Galicyjska prasa pedagogiczna jako źródło wiedzy o rozwoju polskiej myśli pedagogicznej—stan badań, postulaty [Galician pedagogical press as a source of knowledge about the development of Polish pedagogical thought-The state of research, postulates]. Acta Universitatis Nicolai Copernici. Pedagogika, 33(1), 9-25

Duda, R. (1982). Zasada paralelizmu w dydaktyce [Principle of parallelism in didactics]. Dydaktyka Matematyki, 1, 127-137

Duda, R. (1997). Stulecie wiadomości matematycznych [A century of mathematical messages]. Wiadomości Matematyczne, 33, $111-135$

Duda, R. (2011). Przegląd historyczny polskich czasopism matematycznych [Historical overview of Polish mathematical journals]. Wiadomości Matematyczne, 47(2), 167-208

Duda, R. (2019). Historia matematyki w Polsce na tle dziejów nauki $i$ kultury [History of mathematics in Poland against the history of science and culture]. Warszawa: Polish Academy of Sciences.

Dubiel, W. (1989). Polskie czasopisma matematyczno-dydaktyczne i ich funkcje (1911-1939) [Polish journals on mathematical education and their roles (1911-1939)]. Kwartalnik Historii Prasy Polskiej, 28(4), 33-48

Fick, M. (2018). Polskie czasopisma matematyczne w zbiorach Biblioteki Uniwersytetu Śląskiego źródłem wiedzy na temat historii matematyki [Polish Mathematics Journals collected by the Library of the University of Silesia as a source of knowledge about the history of mathematics]. Biblioteka Uniwersytetu Śląskiego w Katowicach. https://rebus.us.edu.pl/bitstream/20. 500.12128/11122/1/Fick_Polskie_czasopisma_matematyczne. pdf

Furinghetti, F., \& Somaglia, A. (2018). The role of a journal on teaching mathematics and sciences issued at the beginning of the 20th century in professionalizing Italian primary school teachers. In F. Furinghetti \& A. Karp (Eds.), Researching the history of mathematics education. An international overview. ICME-13 Monographs. (pp. 79-105). Springer.

Gazeta Wyborcza 23.02. (1999). Wiadomości. Gimnazja, Spór czy je wprowadzać. 1999. [Gymnasium: The dispute whether to enter them. 1999].

Gradient. (1992). Kufer matematyków. Met-El-Mat.

Hejný, M. (1997). Rozwój wiedzy matematycznej [Development of mathematical knowledge]. Dydaktyka Matematyki, 19, 15-28

Hoffman, A. (1992). Dla ciebie, dla dzieci, dla matematyki [For you, for children, for mathematics]. Matematyka, 2(235), 117-121

Journal of Laws. (1990). No. 65 item 385.

Karpiński, M., Swoboda, E., \& Zambrowska, M. (2020). Changes in Polish school mathematics education in the years 1989-2019. In A. Karp (Ed.), Eastern European mathematics education in the decades of changes. (pp. 131-171). Springer.

Klus-Stańska, D. (2005). Publikacje: czy tylko przykłady dobrej praktyki? [Publications: Just examples of good practice?]. Biuletyn Kolegiów Nauczycielskich, 1(28), 32-39

Krygowska, Z. (1954). W sprawie wprowadzania w klasie VIII dyskusji równań [On introducing equations debate in 8th grade]. Matematyka, 1(29), 33-34

Krygowska, Z. (1982). Główne problemy i kierunki badań współczesnej dydaktyki matematyki, [Main problems and trends of research in contemporary didactics of mathematics]. Dydaktyka Matematyki, 1, 7-60

Kurina, F. (1998). Jak myśl uczynić widzialna [How to make the thought visible]. Dydaktyka Matematyki, 20, 73-88

Malicki, T. (1994). Przybij piątkę [High five]. Nauczyciele $i$ Matematyka, 11, 22-24

Musiał, F. (1918). Triumf i pierwszy kryzys "ludowej” Polski 19481956 [Triumph and the first crisis of the Polish People's Republic], In Od niepodległości do niepodległości. Historia Polski 1918-1989 [From independence to independence. History of
Poland 1918-1989], collective work, https://www.polska191889.pl/kultura-i-nauka-w-sluzbie-ideologii,234.html

Legutko, M. (1999). Przed nami reforma [Facing the reform]. Matematyka, 4, 230-233

Niedośpiał, G. (1994). Algebra w ułamkach [Algebra in fractions]. Nauczyciele i Matematyka, 9, 29-31

Nowak, W. (1982). Wybrane zagadnienia metodologii badań dydaktyki matematyki [Selected Problems of the methodology of research on the didactics of mathematics]. Dydaktyka Matematyki, 1, 61-126

Nowecki, B. (1967). Kilka uwag na marginesie reformy nauczania matematyki w szkole [Marginal remarks about the education reform and mathematics teaching at schools]. Wiadomości Matematyczne, 10, 93-97

Ombach, J. (1997). Nowa matura-dyskusja i propozycje [New Matura exam: Debate and proposals]. Wiadomości Matematyczne, $33,197-184$

Pawłowski, J. (1993). Rachunek prawdopodobieństwa + brydż + kalkulator graficzny [Probability \& bridge \& graphing calculator]. Nauczyciele i Matematyka, 8, 17-21

Piecewska-Łoś, A. (2008-2015). Trzynaście ksiąg—seria artykułów o Elementach Euklidesa [The thirteen books-A series of articles on Euclid's 'Elements']. Matematyka w Szkole, pp. 46-80.

Pogoda, Z. (1999). Historia matematyki w Matematyce, [History of mathematics in Mathematics]. In S. Domoradzki, Z. PawlikowskaBrożek, \& D. Węglowska (Eds.), XII Szkoła Historii Matematyki, Krynica 19-25 maja 1998. (pp. 275-278). Berlin: AGH Kraków.

Preveraud, T. (2013). American mathematical journals and the transmission of French textbooks into USA. In Bjarnadóttir, B., Furinghetti, F., Prytz, J., \% Schubring, G. (Eds.), 'Dig where you stand' 3. Proceedings of the Third International Conference on the History of Mathematics Education, Uppsala.

Schnizel, A. (1992). Postęp w teorii liczb w latach 1989-1992 [The progress of number theory in 1989-1992]. Gradient, 7, 1-7

Semadeni, Z. (1982). Reprezentacje enaktywne i reprezentacje ikoniczne w sensie Brunera na przykładzie reprezentacji pojęć mnogościowych [Enactive and iconic representations in Bruner's sense exemplified by representation of set-theoretical notions]. Dydaktyka Matematyki, 1, 163-184

Semadeni, Z. (1990). Tezy raportu o edukacji matematycznej w Polsce [Thesis from the Report on Mathematical Education in Poland]. Wiadomości Matematyczne, 28, 113-121

Sierpiński, W. (1954). Liczba pierwsza o 687 cyfrach [687-digit Prime Number]. Matematyka, 1(29), 3

Stehliková, N. (1999). Metody badawcze stosowane przez uczestników praskiego seminarium z dydaktyki matematyki [Research methods used by members of the Prague Seminar on didactics of mathematics]. Dydaktyka Matematyki, 21, 85-95

Steinbring, H. (1994). Problemy rozwijania wiedzy matematycznej uczniów: przykład lekcji z rachunku różniczkowego [Problems in the development of mathematical knowledge in the classroom: The case of a calculus lesson]. Dydaktyka Matematyki, 16, $103-138$

Straszewicz, S. (1954). Uwaga do artykułu „O równoważności wielokątów" [Remarks on the article 'On the Equivalence of Polygons']. Matematyka, 1(29), 6-7

Turnau, S. (1993). W kolejce do kasy [Standing in the queue]. Nauczyciele i Matematyka, 7, 13-14

Turnau, S. (2003). Jak nie dać się zwariować [How to keep a cool head?]. Matematyka, 4(302), 209-210

Turski, ŁA. (2016). Klęska nauczania matematyki i przedmiotów ścisłych w Polsce w XX wieku. Co można z tym zrobić? [Failure in school teaching of mathematics and sciences in 20th century Poland. What can be done about it?]. Wiadomości Matematyczne, 52(1), 69-76 
Wiadomości Matematyczne, X. X. I. I. (1986). Stanowisko Komitetu Nauk Matematycznych PAN w sprawie szkolnych programów i podręczników matematyki, przyjęte na posiedzeniu plenarnym w dniu 28 lutego 1986 r, [Position of the Committee of Mathematical Sciences of the Polish Academy of Sciences on school programs and textbooks in mathematics, adopted at the plenary session on February 28, 1986, ]. Wiadomości Matematyczne, 22, 190-191

Višňovská, J. (2000). Analiza atomiczna pewnego dialogu. Przedpojęcie prawdopodobieństwa [Atomic analysis of a dialog-Pre-conception of probability]. Dydaktyka Matematyki, $22,147-165$

Wittmann, E. (1993). Dydaktyka matematyki jako 'design science' [Mathematics education as a 'design science'], translated by permission of Kluwer Academie Publishers. Dydaktyka Matematyki, $15,103-115$

Wojciechowska, A. (1999). Matematyka w Matematyce [Mathematics in Matematyka]. In S. Domoradzki, Z. Pawlikowska-Brożek, \& D. Węglowska (Eds.), XII Szkoła Historii Matematyki, Krynica 19-25 maja 1998. (pp. 257-262). AGH Kraków.
Wrona, W. (1955). Konferencja metodyczno-dydaktyczna matematyków w Krakowie [Conference on mathematical methodology and education in Cracow]. Wiadomości Matematyczne, 1(1), 127-129

Wuczyńska, K. (1999). Dydaktyka Matematyka w Matematyce [Didactics of mathematics in Matematyka]. In S. Domoradzki, Z. Pawlikowska-Brożek, \& D. Węglowska (Eds.), XII Szkoła Historii Matematyki, Krynica 19-25 maja 1998. (pp. 263-274). AGH Kraków.

Zając, K. (1999). Matematyka wśród nauczycieli, [Matematyka among the teachers]. In S. Domoradzki, Z. Pawlikowska-Brożek, \& D. Węglowska (Eds.), XII Szkoła Historii Matematyki, Krynica 19-25 maja 1998. (pp. 314-317). AGH Kraków.

Publisher's Note Springer Nature remains neutral with regard to jurisdictional claims in published maps and institutional affiliations. 